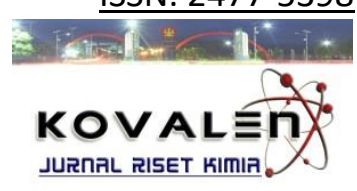

\title{
ANALISIS KADAR $\alpha$-TOKOFEROL (VITAMIN E) DALAM DAUN KELOR (Moringa oleifera Lam) DARI DAERAH PESISIR DAN PEGUNUNGAN SERTA POTENSINYA SEBAGAI ANTIOKSIDAN
}

\author{
[Analysis of $\alpha$-Tokopherol (Vitamin E) Extracted from Moringa Leaves (Moringa oleifera \\ Lam) Collected from Seashore and Highland Areas and Its Potencyl as Antioxidant]
}

\author{
Khalil Mubarak $^{1^{\star}}$, Hasnah Natsir ${ }^{1}$, Abd. Wahid Wahab ${ }^{1}$, Pasjan Satrimafitrah ${ }^{2}$ \\ 1) Jurusan Kimia, Fakultas MIPA, Universitas Hasanuddin \\ Jl. Perintis Kemerdekaan Km 10 Tamalanrea,Makassar, 90245 \\ 2) Jurusan Kimia, Fakultas MIPA, Universitas Tadulako \\ Jl. Soekarno Hatta, Kampus Bumi Tadulako Tondo Palu, Telp. 0451- 422611
}

Diterima 20 Maret 2017, Disetujui 17 April 2017

\begin{abstract}
Alpha-tocopherol, a major vitamin E component, functions as an antioxidant that neutralizes free radicals in a living organism. Moringa oleifera Lam. leaves are rich source of carotenoids and -tocopherol. This research was aimed to determine the concentration of $\alpha$-tocopherol and examine the activity of moringa leaves (Moringa oleifera L.) crude extracts as an antioxidant. Sample used in this research were juvenile and adult moringa leaves (Moringa oleifera $\mathrm{L}$ ), which were taken from seashore of Barru regency and highland of Soppeng regency. Extraction of the leaves was carried out by reflux method using ethanol as a solvent, and then evaporated to produce concentrated ethanol extract. Analyzes were detected at wavelenght of $510.20 \mathrm{~nm}$ using UV-Vis Spectroscopy, the results indicated that concentration of $\alpha$ tocopherol extracted from juvenile and adult moringa leaves from seashore area were $104.52 \mathrm{mg} / 100 \mathrm{~g}$ and $11.419 \mathrm{mg} / 100 \mathrm{~g}$ respectively, whilst the leaves from highland area gave a concentration of 134.4 $\mathrm{mg} / 100 \mathrm{~g}$ and $114.918 \mathrm{mg} / 100 \mathrm{~g}$. Next, we examined the antioxidant activity of each type of leaf using DPPH (1,1-diphenyl-2-picrylhydrazyl) methods at the wavelength of $515 \mathrm{~nm}$. The $\mathrm{IC}_{50}$ results data showed that ethanol extract of juvenile and adult leaves from seashore area were $172.71 \mu \mathrm{g} / \mathrm{mL}$ and $258.92 \mu \mathrm{g} / \mathrm{mL}$ respectively, and categorized as weak antioxidant. Adversely, juvenile leaves from highland area gave a result of $97.79 \mu \mathrm{g} / \mathrm{mL}$ and categorized as strong antioxidant; while adult leaves from the same area gave a values of $143.14 \mu \mathrm{L} / \mathrm{mL}$ and categorized as medium antioxidant. Vitamin $\mathrm{E}$ and BHT were used as control and had higher values compared to all samples.
\end{abstract}

Keywords: $\alpha$-tocopherol, antioxidant, Moringa oleifera leaves, DPPH, UV-Vis Spectrophotometer.

\begin{abstract}
ABSTRAK
Vitamin E atau $\alpha$-tokoferol merupakan vitamin yang larut dalam lemak dan dapat berfungsi sebagai antioksidan sehingga mampu menetralisir radikal bebas dalam tubuh mahkluk hidup. Penelitian ini bertujuan untuk menentukan kadar $\alpha$-tokoferol dan menguji aktivitas antioksidan dari daun kelor (Moringa oleifera L). Ekstraksi senyawa $\alpha$-tokoferol dilakukan menggunakan metode refluks dengan pelarut etanol p.a, yang selanjutnya dievaporasi untuk menghasilkan ekstrak etanol kental. Sampel yang digunakan adalah daun kelor yang muda dan tua yang berasal dari daerah pesisir pantai Kabupaten Barru dan pegunungan Kabupaten Soppeng. Hasil analisis menggunakan spektrofotometer UV-Vis pada panjang gelombang $(\lambda) 510,20 \mathrm{~nm}$, menunjukkan: kandungan a-tokoferol pada daun kelor muda dan tua dari kawasan pesisir pantai adalah $104,52 \mathrm{mg} / 100 \mathrm{~g}$ dan $116,419 \mathrm{mg} / 100 \mathrm{~g}$, sedangkan daun kelor muda dan daun kelor tua dari kawasan pegunungan adalah $134,40 \mathrm{mg} / 100 \mathrm{~g}$ dan $114,92 \mathrm{mg} / 100 \mathrm{~g}$. Selanjutnya, pengujian aktivitas antioksidan dilakukan dengan metode DPPH (1,1-difenil-2-pikrilhidrazil) pada panjang gelombang $515 \mathrm{~nm}$ menghasilkan data $\mathrm{IC}_{50}$ sebagai berikut: ekstrak daun kelor muda dan daun kelor tua pesisir masing-masing adalah $172,71 \mu \mathrm{g} / \mathrm{mL}$ dan $258,92 \mu \mathrm{g} / \mathrm{mL}$ yang dikategorikan sebagai antioksidan lemah; sedangkan daun kelor muda dari kawasan pegunungan adalah $97,79 \mu \mathrm{g} / \mathrm{mL}$ yang tergolong antioksidan kuat; dan daun kelor tua dari kawasan pegunungan bernilai $143,14 \mu \mathrm{g} / \mathrm{mL}$ yang dikategorikan sebagai antioksidan sedang. Sebagai konrol positif untuk antioksidan digunakan Vitamin E dan BHT dimana nilai $\mathrm{IC}_{50}$ dari Vitamin $\mathrm{E}$ dan $\mathrm{BHT}$ lebih kuat dibandingkan dengan semua sampel daun kelor.
\end{abstract}

Kata kunci : $\alpha$-Tokoferol, Antioksidan, Daun Kelor, DPPH, Spekrtrofotometer UV-Vis. 


\section{LATAR BELAKANG}

Penelitian di dunia kesehatan saat ini semakin berkembang, sehingga memunculkan pemahaman bahwa kerusakan pada sel dan jaringan yang merupakan akar dari sebagian besar penyakit disebabkan oleh kelompok senyawa kimia yang disebut 'radikal bebas (Youngson, 2005). Radikal bebas masuk ke dalam tubuh dapat melalui pernapasan, makanan berlemak, dan kondisi lingkungan yang tidak sehat (Lestario dkk, 2009). Oleh karena keberadaan radikal bebas, maka tubuh memerlukan komponen penting yang menangkal serangan radikal bebas tersebut yaitu antioksidan.

Antioksidan merupakan senyawa yang bekerja dengan menghambat laju oksidasi molekul lain atau menetralisir radikal bebas (Fajriah dkk, 2007). Seiring dengan semakin bertambahnya pengetahuan manusia tentang aktivitas radikal bebas terhadap beberapa penyakit degeneratif, maka penggunaan antioksidan juga semakin berkembang (Ikhlas, 2013).

Manusia membutuhkan antioksidan yang dapat melindungi tubuh dari serangan radikal bebas, mengingat begitu banyaknya radikal bebas yang berasal dari luar tubuh, seperti makanan yang banyak mengandung asam lemak tidak jenuh, bahan pengawet, pestisida, dan pewarna (Zuhra, dkk., 2008; Parwata dkk, 2010). Oleh karena itu, asupan makanan yang mengandung antioksidan dibutuhkan oleh tubuh agar dapat menagkal serangan radikal bebas. Antioksidan alami tersebut berupa vitamin $\mathrm{C}$, tokoferol (vitamin $\mathrm{E}$ ), betakaroten, dan antioksidan fitokimia dari golongan fenolik (Ikhlas, 2013). Sumber antioksidan alami ini dapat diperoleh dari buah-buahan dan sayur-sayuran salah satu contohnya adalah kelor.

Tumbuhan Kelor (Moringa oleifera) merupakan jenis tumbuhan yang awalnya berasal dari kawasan sekitar Himalaya dan India, kemudian menyebar ke Benua Asia, Amerika, Afrika, dan New Zealand. Kelor merupakan pohon sayuran yang sangat bergizi, memiliki berbagai manfaat (Luthfiyah, 2012). Daun kelor mengandung berbagai zat kimia yang bermanfaat. Kandungan fitokimia dalam daun kelor diantaranya tanin, steroid dan triterpenoid, flavonoid, saponin, antarquinon, dan alkaloid serta mengandung mineral, asam amino esensial, antioksidan, dan vitamin (Hardiyanthi, 2015).

Salah satu kandungan tanaman kelor yang paling berkhasiat adalah antioksidan, terutama pada bagian daunnya yang mengandung antioksidan tinggi, salah satunya vitamin $E$ ( $\alpha$ tokoferol). Vitamin E (a-tokoferol) dipercaya sebagai sumber antioksidan yang kerjanya mencegah lipid peroksidasi dari asam lemak tak jenuh dalam membran sel dan membantu oksidasi vitamin A serta mempertahankan kesuburan (Rohmatussolihat, 2009). 
Berdasarkan penelitian yang dilakukan oleh Unigbe dkk (2014), daun kelor (Moringa oleifera) dapat digunakan sebagai antioksidan alami dengan mencegah kerusakan yang ditimbulkan oleh radikal bebas dengan nilai $I_{50}$ berkisar 5,72-42,56 $\mu \mathrm{g} / \mathrm{mL}$. Menurut Fatchurrozak dkk (2013), ketinggian suatu tempat dari permukaan laut merupakan salah satu faktor yang sangat berpengaruh terhadap pertumbuhan tanaman. Daerah pesisir dan daerah pegunungan memiliki perbedaan faktor lingkungan. Semakin tinggi ketinggian tempatnya, maka semakin tinggi pula stress terhadap lingkungan. Ketika suatu tanaman mengalami stress, maka produksi metabolit sekunder termasuk produksi vitamin akan mengalami peningkatan (Fatchurrozak dkk, 2013).

\section{METODE PENELITIAN}

\section{Bahan dan Peralatan}

Bahan yang digunakan daun kelor (Moringa oleifera Lam.) berdasarkan letak pertumbuhannya, yaitu yang berada di daerah pesisir Kabupaten Barru dan pegunungan Kabupaten Soppeng, padatan vitamin $\mathrm{E}$ ( $\alpha$-tokoferol), etanol $96 \%$, kloroform, lodida $0,1 \%$, metanol, DPPH (1,1-difenil-2-pikrilhidrazi), Butil Hidroksi Tuluen (BHT), kertas saring whatman no. 42, aluminium foil, plastik wrap dan tissue roll.

Peralatan berupa labu alas bulat, kondensor refluks, corong kaca, Corong Buchner, klem, statif, hotplate, selang, cool box, Evaporator Rotary, termometer, neraca analitik, mikro pipet, cuvet, spektrofotometer UV-Vis, vortex dan vial. Alat-alat gelas yang biasa digunakan di laboratorium seperti labu ukur, gelas ukur, gelas kimia, buret, pipet tetes, tabung reaksi dan rak tabung.

\section{Prosedur Kerja}

\section{Preparasi Sampel}

Daun kelor (Moringan oleifera Lam.) yang digunakan adalah daun kelor muda yang dipetik dari dahan pohon yang kurang lebih dari tangkai daun pertama (di bawah pucuk) sampai tangkai daun ketujuh yang masih hijau, dan daun tua kecuali daun yang menguning. Selanjutnya daun kelor tersebut dicuci dengan air bersih lalu dirunut dari tangkai daunnya, kemudian dihaluskan dengan menggunakan blender.

\section{Ekstraksi Sampel}

Sampel ditimbang sebanyak 150 gram kemudian di isolasi dengan menggunakan metode refluks. Refluks dilakukan dengan cara sampel daun kelor sebanyak 150 gram tadi dimasukkan ke dalam labu alas bulat 1 liter dan dutambahkan etanol $96 \%$ sebagai cairan penyari sebanyak $200 \mathrm{~mL}$. Refluks dilakukan selama 3 jam pada suhu $80^{\circ} \mathrm{C}$. Hasil isolasi kemudian di saring dan selanjutnya dievaporasi untuk menguapkan pelarut guna mendapatkan ekstrak kental. Ekstrak kental yang diperoleh ditimbang. 
Pembuatan Larutan Standar a-tokoferol (Vitamin E) 1000 ppm

Padatan a-tokoferol (Vitamin E) ditimbang sebanyak $50 \mathrm{mg}$, kemudian dimasukkan ke dalam labu takar $50 \mathrm{~mL}$ lalu dilarutkan dengan sedikit kloroform. sampai tanda batas. Kemudian ditambahkan $1 \mathrm{~mL}$ iodida $0,1 \%$ ke dalam larutan baku, dikocok hingga membentuk warna ungu. Setelah itu, diimpitkan dengan klorofrm sampai tanda batas. Kocok sampai homogen

Pembuatan Larutan Standar a-tokoferol (Vitamin E) 10 ppm; 20 ppm; 40 ppm; 80 ppm; 160 ppm dan 320 ppm

Larutan standar a-tokoferol (vitamin E) 1000 ppm masing-masing dipipet sebanyak 0,05 mL; $0,1 \mathrm{~mL} ; 0,2 \mathrm{~mL} ; 04$ $\mathrm{mL} ; 0,8 \mathrm{~mL}$ dan $1,6 \mathrm{~mL}$ ke dalam labu ukur $5 \mathrm{~mL}$. Kemudian ditambahkan $1 \mathrm{~mL}$ iodida $0,1 \%$ ke dalam larutan baku, dikocok hingga membentuk warna ungu. Setelah itu, diimpitkan dengan klorofrm sampai tanda batas. Kocok sampai homogen.

\section{Penentuan Panjang Gelombang Maksimum (A maks)}

Penentuan panjang gelombang maksimum ( $\lambda$ maks) diperoleh dengan mengukur absorbansi larutan standar a-tokoferol (vitamin E) pada panjang gelombang $(\lambda)$ 550-600 nm. Berdasarkan pengukuran larutan standar tersebut diperoleh panjang gelombang maksimum.

\section{Penetapan Kadar a-tokoferol (Vitamin E)}

Ekstrak kental yang diperoleh ditimbang sebanyak $10 \mathrm{mg}$ kemudian diencerkan menggunakan $9 \mathrm{~mL}$ kloroform. Ditambahkan $1 \mathrm{~mL}$ iodida $0,1 \%$, dikocok sampai homogen, diukur absorbansinya pada panjang gelombang maksimum yang didapat. Hasil absorbansi dibandingkan dengan kurva linier larutan standar a-tokoferol (Vitamin E) untuk memperoleh kadar vitamin E pada ekstrak yang diperoleh.

\section{Uji Aktivitas Antioksidan dengan Metode DPPH}

\section{- Pembuatan larutan DPPH}

Larutan DPPH $0,4 \quad \mathrm{mM}$ dibuat dengan cara menimbang 7,9 mg DPPH dan dilarutkan dengan metanol p.a hingga $50 \mathrm{~mL}$ dalam labu ukur.

\section{Penentuan panjang gelombang maksimum ( $\left.\lambda_{\text {maks }}\right)$ DPPH}

Larutan blanko dibuat dengan cara memipet $1 \mathrm{~mL}$ larutan DPPH 0,4 mM kemudian dicukupkan volumenya hingga $5 \mathrm{~mL}$ dengan methanol p.a. Setelah itu dibiarkan selama 30 menit ditempat gelap, serapan larutan diukur dengan spektrofotometer UV-Vis pada panjang gelombang 400-600 nm.

\section{- Pembuatan larutan pembanding} (Vitamin E dan BHT)

Vitamin $\mathrm{E}$ dan BHT masing-masing ditimbang sebanyak $10 \mathrm{mg}$ dan dilarutkan dalam $10 \mathrm{~mL}$ metanol p.a sehingga diperoleh konsentrasi 1000 ppm sebagai larutan induk, kemudian diencerkan menjadi 100ppm. Dari larutan induk dibuat seri konsentrasi 1 , 2, 3, 4 dan 5 ppm dengan memipet berturut-turut $50,100,150,200$, dan 
$250 \mu \mathrm{L}$. Larutan DPPH ditambahkan sebanyak $1 \mathrm{~mL}$ dan dicukupkan volumenya hingga $5 \mathrm{~mL}$ dengan metanol p.a.

\section{- Pengujian Aktivitas Antioksidan}

Larutan induk dari ekstrak daun kelor yang telah diketahui konsentrasinya dibuat dalam 5 seri konsentrasi yaitu 10, 20, 30, 20 dan 50 ppm. Larutan DPPH ditambahkan sebanyak $1 \mathrm{~mL}$, dan dicukupkan volumenya hingga $5 \mathrm{~mL}$ dengan metanol p.a, dan sebagai pembanding digunakan vitamin $\mathrm{C}$ dan $\mathrm{BHT}$ (butil hidroksi toluen) dengan seri konsentrasi 1, 2, 3, 4 dan 5 ppm. Campuran tersebut dikocok dan dibiarkan selama 30 menit pada suhu kamar dan pada ruangan yang terlindungi dari cahaya matahari. Absorbansi (A) diukur pada panjang gelombang maksimum dengan spektrofotometer UV-Vis. Selanjutnya dihitung persentase inhibisi (hambatan) dan $\quad I_{50} \quad(50 \% \quad$ Inhibition Concentration). Perhitungan kuantitatif dilakukan dengan menentukan persen inhibisi radikal bebas dari masingmasing sampel yang dihitung menggunakan persamaan dibawah ini (Molyneux, 2004):

\footnotetext{
$\%$ Inhibisi $=\frac{\text { Abs Kontrol-Abs Sampel }}{\text { Abs Konrol }} \times 100 \%$ Keterangan:

Abs kontrol $=$ Absorbansi DPPH + metanol Abs sampel $=$ Absorbansi DPPH + sampel
}

Selanjutnya nilai \% inhibisi digunakan untuk menghitung nilai $\mathrm{IC}_{50}(\mathrm{ppm})$.
HASIL DAN PEMBAHASAN

Hasil Analisis Kadar a-Tokoferol

Tabel 1. Kadar $\alpha$-Tokoferol dalam Daun Kelor

\begin{tabular}{ccc}
\hline $\begin{array}{c}\text { Jenis } \\
\text { Daun }\end{array}$ & Satuan & $\begin{array}{c}\text { Kadar } \boldsymbol{\alpha} \text {-Tokoferol } \\
\text { per } \mathbf{1 0 0} \text { gram }\end{array}$ \\
\hline DKMP & $\mathrm{mg}$ & 104,52 \\
DKTP & $\mathrm{mg}$ & 117,52 \\
DKMG & $\mathrm{mg}$ & 134,41 \\
DKTG & $\mathrm{mg}$ & 114,92 \\
\hline
\end{tabular}

Keterangan:

DKMP = Daun Kelor Muda Pesisir;

DKTP = Daun Kelor Tua Pesisir;

DKMG = Daun Kelor Muda Pegunungan;

DKTG = Daun Kelor Tua Pegunungan;

Pada Tabel 1 menunjukkan kadar a-Tokoferol (Vitamin E) daun kelor daerah pegunungan lebih tinggi daripada di daerah pesisir. Hasil tersebut sama dengan pendapat Karamoy (2009), ia mengemukakan bahwa pengaruh ketinggian tempat berkaitan dengan proses metabolisme suatu tanaman, seperti proses biokimia dan sintesis senyawa metabolit sekunder seperti vitamin. Hal ini akan mempengaruhi pertumbuhan, karakter morfologi, maupun kandungan senyawa aktif pada suatu tanaman.

Tanaman yang tumbuh pada ketinggian yang tinggi biasanya memiliki ciri-ciri morfologi yang khas, termasuk pertumbuhan yang kerdil karena penyesuaian morfologi dan fisiologis yang memungkinkan individu untuk bertahan dalam lingkungan tercekam yang dikaitkan dengan ketinggian tempat tumbuh (Bresson dkk, 2011). Semakin tinggi ketinggian tempatnya, maka semakin tinggi pula stress lingkungan, misalnya suhu semakin rendah, kelembaban 
semakin tinggi, intensitas cahaya matahari semakin kecil, lama penyinaran semakin singkat. Stres suhu, cahaya, kelembaban, dan lain-lain dapat mempengaruhi produksi vitamin tanaman. Ketika tanaman mengalami stress, maka vitamin $E$ mengalami peningkatan (Fatchurrozak, dkk, 2013).

Khusus untuk daerah pegunungan, intensitas cahaya matahari semakin berkurang seiring dengan semakin tingginya suatu tempat, cahaya matahari mempengaruhi tumbuhan berdaun hijau karena cahaya matahari sangat menentukan proses fotosintesis. Fotosintesis merupakan proses pada tumbuhan untuk menghasilkan makanan. Makanan yang dihasilkan akan menentukan ketersediaan energi untuk pertumbuhan dan perkembangan tumbuhan (Aryulina dkk, 2006 dalam Artanti dkk, 2016). Menurut penelitian yang dilakukan oleh Ayua dkk (2016), daun muda aktif secara fisiologis dari daun tua. Daun muda memerlukan lebih banyak vitamin, akan tetapi tidak bisa mengumpulkan cukup vitamin untuk memenuhi proses fisiologisnya. Sebaliknya, daun tua memiliki kemampuan yang tinggi untuk mensintesis vitamin tetapi pemanfaatannya lebih rendah. Nutrisi selalu disimpan dalam daun tua dan kemudian ditransfer ke daun muda untuk pertumbuhan dan perkembangannya. Daun muda tidak memiliki bentuk organ untuk penyimpanan nutrisi. Akibatnya, translokasi nutrisi lebih banyak pada daun muda daripada daun tua.

\section{Hasil Uji Analisis Antioksidan dengan Metode DPPH}

Penentuan daya peredaman radikal bebas dipilih metode DPPH, hal ini didasarkan pada beberapa keunggulannya, diantaranya mudah, sederhana, cepat, reprodusibel, baik untuk sampel dengan polaritas tertentu, sensitif, dan hanya membutuhkan sedikit sampel (Koleva dkk., 2002 dan Kurniasih dkk., 2015). Selain itu, DPPH merupakan radikal bebas yang relatif stabil jika dibandingkan dengan radikal bebas yang lain dan mudah diperoleh dipasaran yang siap untuk dilarutkan serta mudah direaksikan dengan larutan uji (Larson, 1997).

Ekstrak uji yang digunakan adalah ekstrak daun kelor dari hasil analisis asam askorbat, kemudian dilanjutkan pengujian antioksidan dengan metode DPPH secara kuantitatif menggunakan spektrofotometer UV pada panjang gelombang $515 \mathrm{~nm}$. Menurut Molyneux (2004), panjang gelombang tersebut dapat digunakan sebab panjang gelombang dari absorbansi maksimum yang dapat digunakan untuk pengukuran dengan metode DPPH yaitu 515-520 nm. Panjang gelombang yang diperoleh selanjutnya digunakan untuk pengukuran kontrol dan sampel. 


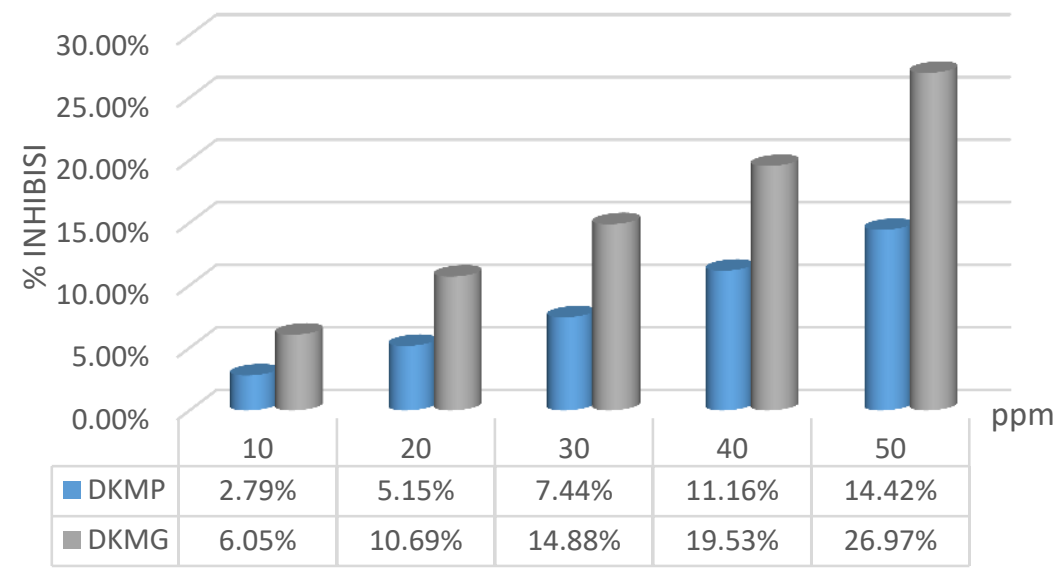

(a)

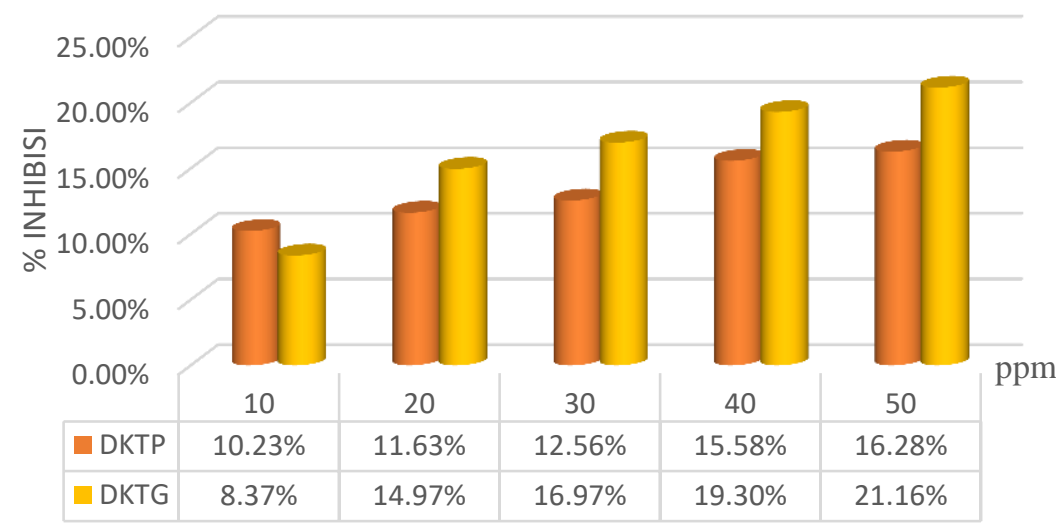

(b)

Gambar 1. Grafik Aktivitas Antioksidan (a) Daun Kelor Muda dan (b) Daun Kelor Tua Daerah Pesisir dan Daerah Pegunungan

Dari Gambar 1 dapat dilihat bahwa nilai \% inhibisi di daerah pegunungan lebih tinggi daripada di daerah pesisir. Semakin tinggi konsentrasi sampel maka aktivitas antioksidan akan semakin besar pula. Hasil ini didukung oleh penelitian Hanani dkk (2005) yang menyatakan bahwa persentase penghambatan (\% inhibisi) terhadap aktivitas radikal bebas akan meningkat dengan maningkatnya konsentrasi. Tinggi atau rendahnya aktivitas antioksidan sampel dengan metode penangkapan radikal DPPH ini diketahui dari persentase inhibisinya. Semakin besar nilai persentase inhibisi sampel maka semakin tinggi aktivitas antioksidannya. Proses inhibisi terjadi ketika radikal DPPH bereaksi dengan senyawa antioksidan melalui pengambilan ion hidrogen (Reynetrson, 2007 dalam Wachidah, 2013).

Parameter yang dugunakan untuk menunjukkan aktivitas antioksidan adalah Inhibition Concentration $\left(\mathrm{IC}_{50}\right)$ yaitu konsentrasi suatu zat antioksidan yang dapat menyebabkan 50\% DPPH kehilangan karakter radikal atau konsentrasi suatu zat antioksidan yang memberikan persen penghambatan $50 \%$. Jika aktivitas antioksidannya semakin tinggi maka nilai $\mathrm{IC}_{50}$ akan semakin kecil 
(Molyneux, 2004). Persen inhibisi ini didapatkan dari perbedaan serapan antara absorbansi DPPH dengan aborbansi sampel yang diukur menggunakan spektrofotometer UV-Vis (Andayani dkk,
2008). Nilai $I_{50}$ ekstrak daun kelor (Moringa oleifera Lam) dan pembanding (kontrol positif) vitamin $\mathrm{E}$ dan $\mathrm{BHT}$ diperoleh berdasarkan perhitungan regresi linear dari kurva absorbansi sampel.

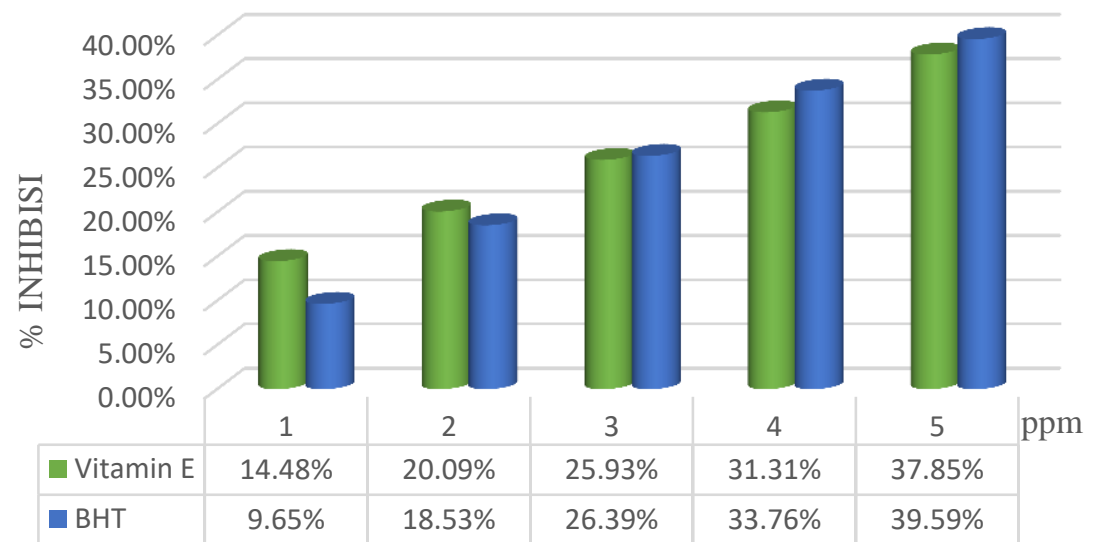

Gambar 2. Grafik Aktivitas Antioksidan Vitamin E dan BHT

Tabel 2. Nilai $I_{50}$ dan Tingkat Kekuatan Antioksidan Sampel Daun Kelor dan Pembanding (Kontrol Positif)

\begin{tabular}{ccc}
\hline $\begin{array}{c}\text { Sampel/ } \\
\text { pembanding }\end{array}$ & Nilai IC $_{50}$ & Intensitas \\
\hline \multicolumn{3}{c}{ Sampel } \\
\hline DKMP & $172,71 \mu \mathrm{g} / \mathrm{mL}$ & Lemah \\
DKTP & $258,92 \mu \mathrm{g} / \mathrm{mL}$ & Lemah \\
DKMG & $97,79 \mu \mathrm{g} / \mathrm{mL}$ & Kuat \\
DKTG & $143,14 \mu \mathrm{g} / \mathrm{mL}$ & Sedang \\
\hline \multicolumn{4}{c}{ Pembanding (Kontrol Positif) } \\
\hline Vitamin E & $7,15 \mu \mathrm{g} / \mathrm{mL}$ & Sangat Kuat \\
BHT & $6,25 \mu \mathrm{g} / \mathrm{mL}$ & Sangat Kuat \\
\hline
\end{tabular}

Dilihat dari Tabel 2, Jika dibandingkan dengan vitamin $\mathrm{E}$ dan $\mathrm{BHT}$ yang merupakan antioksidan sangat kuat, sampel DKMP dan DKTP dikategorikan antioksidan lemah, DKMG dikategorikan antioksidan kuat dan DKTG dikategorikan antioksidan sedang. Berdasarkan penelitian yang dilakukan oleh Hasanah dkk (2016), nilai $I_{50}$ dari ekstrak etanol sebesar $363,75 \mu \mathrm{g} / \mathrm{mL}$ sedangkan pembandingnya yaitu vitamin $\mathrm{E}$ sebesar $4,91 \mu \mathrm{g} / \mathrm{mL}$. Hal ini membuktikan bahwa ekstrak etanol daun kelor dikategorikan sebagai antioksidan lemah. Selain itu, dapat dilihat dari perubahan warna yang ditimbulkan menurut Molyneux (2004), pada vitamin $E$ terjadi perubahan warna dari ungu menjadi kuning jernih sedangkan untuk ekstrak etanol daun kelor tidak terjadi perubahan warna seperti yang terjadi pada vitamin E. Dapat disimpulkan bahwa daya aktivitas antioksidan ekstrak etanol daun kelor sangat kecil bila dibandingkan dengan daya aktivitas antioksidan vitamin $\mathrm{E}$, bila dilihat dari nilai $\mathrm{IC}_{50}$.

Hasil yang diperoleh menunjukkan bahwa ekstrak daun muda mempunyai daya peredam radikal bebas yang lebih besar dibanding ekstrak daun tua. Hal ini terjadi karena kandungan vitamin pada daun dapat berbeda-beda karena perbedaan umur dan bagian tanaman 
(Achakzai dkk, 2009). Daun muda umumnya memiliki kandungan vitamin dan enzim yang tinggi karena diperlukan dalam proses pertumbuhan, perkembangan, dan pembelahan sel-sel daun tersebut. Pada perkembangannya konsentrasi metabolit sekunder tanaman akan berangsur menurun seiring penurunan aktivitas perkembangan daun tersebut (Prayitno \& Nuryandani, 2011). Hal ini sesuai dengan penelitian yang dilakukan oleh Harahap (2015), bahwa aktivitas antioksidan daun gaharu (Aquilaria malaccensis Lamk) dengan menggunakan spektrofotometer sinar tampak diperoleh $\mathrm{IC}_{50}$ daun muda sebesar 39,70 ppm dan 40,03 ppm daun tua dari daerah Langka, sedangkan daun muda dan daun tua dari Arboretum Universitas Sumatera Utara memiliki $I_{50}$ sebesar 30,65 ppm dan 43,20 ppm.

Berdasarkan hasil penelitian didapatkan bahwa ekstrak daun kelor daerah pesisir memiliki nilai $I_{50}$ lebih tinggi dibandingkan daun kelor daerah pegunungan, artinya daun kelor daerah pegunungan memiliki aktivitas antioksidan lebih tinggi dibandingkan daerah pesisir. Perbedaan ketinggian tempat berpengaruh terhadap kelembaban, suhu, intensitas cahaya, dan curah hujan. Semakin tinggi dataran/daerah, maka semakin rendah suhu udaranya, dan intensitas cahaya matahai akan semakin berkurang, sehingga mempengaruhi proses fisiologis tanaman, karena proses fisiologi tanaman bergantung pada cahaya matahari (Hidayah, 2011). Hal ini sesuai dengan penelitian yang dilakukan oleh Hidayah (2011), pengaruh ketinggian tempat tumbuh yang berbeda mempengaruhi aktivitas antioksidan teh kombucha rosella. Aktivitas antoksidan pada ketinggian tempat $21 \mathrm{mdpl}(66,88 \%)$ lebih tinggi dibandingkan ketinggian 1100 mdpl (53,60\%).

Tanaman kelor (Moringa oleifera Lam) yang tumbuh di daerah pesisir (Kab. Barru) dan pegunungan (Kab. Soppeng) memiliki kandungan antioksidan yang berbeda dikarenakan pengaruh cahaya terhadap fotosintesis sebagian besar sangat bergantung kepada intensitas yang mempengaruhi pertumbuhan. Dapat dipahami perbedaan respons dalam hal ini terletak pada perbedaan stres lingkungan yang diperoleh tanaman. Fitter \& Hay (1991) menerangkan bahwa respons karakteristik pertumbuhan tanaman terhadap temperatur muncul karena tingginya temperatur mempengaruhi proses biokimia. Dengan naiknya temperatur sel tanaman, kecepatan pergerakan (vibrasi, rotasi, dan translasi dari molekul-molekul yang bereaksi bertambah), menyebabkan tabrakan antar molekul yang semakin sering, dan laju reaksi yang semakin cepat. Semua reaksi yang terjadi di dalam sel dipercepat oleh enzim. Dengan naiknya temperatur, peningkatan rangsangan molekuler cenderung merusak struktur, yang diikuti oleh penurunan aktivitas enzim dan laju reaksi. 


\section{KESIMPULAN}

Kadar $\alpha$-Tokoferol dalam daun kelor (Moringa oleifera Lam.) muda dan tua pesisir sebesar 104,52 dan 117,52 $\mathrm{mg} / 100 \mathrm{~g}$, sedangkan daun kelor (Moringa oleifera Lam.) muda dan tua pegunungan memiliki kadar $\alpha$-Tokoferol sebesar 134,41 dan $114,92 \mathrm{mg} / 100 \mathrm{~g}$.

Hasil pengujian aktivitas antioksidan dengan menggunakan spektrofotometer UV-Vis diperoleh hasil ekstrak daun kelor (Moringa oleifera Lam.) muda pesisir dan pegunungan memiliki $I_{50}$ sebesar 172,71 $\mu \mathrm{g} / \mathrm{mL}$ yang dikategorikan sebagai antioksidan lemah dan $97,79 \mu \mathrm{g} / \mathrm{mL}$ yang dikategorikan sebagai antioksidan kuat serta hasil ekstrak daun kelor (Moringa oleifera Lam.) tua pesisir dan pegunungan memiliki $\mathrm{IC}_{50}$ sebesar $258,92 \mu \mathrm{g} / \mathrm{mL}$ yang dikategorikan sebagai antioksidan lemah dan $143,14 \mu \mathrm{g} / \mathrm{mL}$ yang dikategorikan sebagai antioksidan sedang. Sebagai kontrol positif vitamin $E$ dengan nilai $I_{50}$ sebesar 7,15 $\mu \mathrm{g} / \mathrm{mL}$ dan BHT adalah 6,25 $\mu \mathrm{g} / \mathrm{mL}$.

\section{DAFTAR PUSTAKA}

Achakzai A.K.K., Achakzai P., Masood A., Kayan S.A., Tareen, R.B. 2009. Response of Plant Parts and Age on The Distribution of Secondary Metabolites on Plants Found in Quetta. Pak J. Bot. 41 (5): 21292135.

Andayani R., Maimunah, Lisawati Y. 2008. Penentuan Aktivitas Antioksidan, Kadar Fenolat Total dan Likopen pada Buah Tomat (Solanum lycopersicum L). Jurnal Sains dan Teknologi Farmasi. 13 (1).
Artanti A.N., Nikmah W.R., Setiawan D.H., Prihapsara F. 2016. Perbedaan Kadar Kafein Daun Teh (Camellia sinensis (L.) Kuntze) Berdasarkan Status Ketinggian Tempat Tanam Dengan Metode HPLC. Journal of Pharmaceutical Science and Clinical Research. 1: 37-44.

Ayua E., Mugalavai V., Simon J., Weller S., Obura P., Nyabinda N. 2016. Ascorbic Acid Content In Leaves Of Nightshade (Solanum sp.) and Spider Plant (Cleome gynandra) Varieties Grown Under Different Fertilizer Regimes in Western Kenya. African Journal of Biotechnology. 15 (7): 199-206.

Bresson C.C., Vitasse Y., Kremer A., Delzon S. 2011. to What Extent Is Altitudinal Variation of Functional Traits Driven by Genetic Adaptation in European Oak And Beech?. Tree Physiology 00, 1-11.

Fajriah S., Darmawan A., Sundowo A., Artanti. 2007. Isolasi Senyawa Antioksidan dari Ekstrak Etil Asetat Daun Benalu (Dendrophthoe petandra L. Miq) yang Tumbuh pada Inang Lobi-lobi. Jurnal Kimia Indonesia. 2 (1): 17-20.

Fatchurrozak, Suranto, Sugiyarto. 2013. Pengaruh Ketinggian Tempat Terhadap Kandungan Vitamin $\mathrm{C}$ dan Zat Antioksidan Pada Buah Carica pubescens di Dataran Tinggi Dieng. El-Vivo. 1 (1): 24-31.

Fitter A.H., Hay R.K.M. 1991. Fisiologi Lingkungan Tanaman. Yogyakarta: Gadjah Mada University Press.

Hanani E., Mun'im A., Sekarini R. 2005. Identifikasi Senyawa Antioksidan Dalam Spons Callyspongia sp. dari Kepulauan Seribu. Majalah IImu Kefarmasian. 2 (3): 127-133.

Harahap RH. 2015. Uji Antioksidan Daun Muda dan Daun Tua Gaharu (Aquilaria malaccensis Lamk) Berdasarkan Perbedaan Tempat Tumbuh Pohon. [Skripsi]. Medan: Program Studi Kehutanan, Fakultas 
Kehutanan, Universitas Sumatera Utara.

Hardiyanthi F. 2015. Pemanfaatan Aktivitas Antioksidan Ekstrak Daun Kelor (Moringa oleifera) dalam Sediaan Hand And Body Cream [Skrips]. Jakarta: UIN Syarif Hidayatullah.

Hasanah N., Susilo, J., dan Oktianti, D. 2016. Uji Aktivitas Antioksidan Ekstrak Etanol Daun Kelor (Moringa oleifera Lamk) dengan Metode DPPH, Jurnal Gizi dan Kesehatan, 8 (17).

Hidayah N. 2011. Pengaruh Ketinggian Tempat Tumbuh Rosella dan Jenis Bahan Rosella Terhadap Aktivitas Antioksidan Teh Kombucha Rosella, [Skripsi]. Malang: Fakultas Sains dan Teknologi, UIN Maulana Malik Ibrahim.

Ikhlas N. 2013. Uji Aktivitas Antioksidan Ekstrak Herba Kemangi (Ocimum americanum Linn) dengan Metode DPPH (2,2-Dofenil-1-Pikrilhidrazil) [Skripsi]. Jakarta: UIN Syarif Hidayatullah.

Karamoy L. 2009. Hubungan Antara Iklim dengan pertumbuhan Kedelai (Glicine max L. Merrill). Soil Environment, 7 (1): 65-68.

Koleva II, Van Beek TA, Linssen JPH, de Groot A, Evstatieva LN. 2002. Screening of plant extracts for antioxidant activity: a comparative study on three testing methods. Phytochemical Analysis. 13: 8-17.

Kurniasih N., Kusmiyati M., Nurhasanah, Sari R.P., Wafdan R. 2015. Potensi Daun Sirsak (Annona muricata Linn), Daun Binahong (Anredera cordifolia (Ten) Steenis), dan Daun Benalu Mangga (Dendrophthoe pentandra) Sebagai Antioksidan Pencegah Kanker, ISSN 1979-8911, 9 (1): 162-184.

Larson, R. A., 1997, Naturally Occuring Antioxidan, Lewis Publisher, New York.
Lestario L.N., Christian, A.E., dan Martono, Y. 2009. Aktivitas Antioksidan Daun Gingseng Jawa (Talinum paniculatum Gaertn), Agritech. 29 (2).

Luthfiyah F. 2012. Potensi Gizi Daun Kelor (Moringa oleifera) Nusa Tenggara Barat, Media Bina IImiah. 6 (2): 1978-3787.

Molyneux P. 2004. The Use of Stable Free Radical Diphenylpicrylhydrazyl (DPPH) for Estimating Antioxidant Activity. Songklanakarian $J \mathrm{Sci}$ Technol, 26 (2): 211-219.

Parwata A., Ratnayani K., Listya A. 2010. Aktivitas Antiradikal Bebas Serta Kadar Beta Karoten Pada Madu Randu (Ceiba pentandra) dan Madu Kelengkeng (Nephelium Longata L.). Jurnal Kimia, 4(1): 5462.

Prayitno E., Nuryandani E. 2011. Optimalisasi Ekstraksi DNA Jarak Pagar (Jatropha curcas) Melalui Pemilihan Daun yang Sesuai. Nusantara Bioscience. 3: 1-6.

Rohmatussolihat. 2009. Antioksidan Penyelamat Sel-Sel Tubuh Manusia, Bio Trends. 4 (1).

Wachidah L.N. 2013. Uji Aktivitas Antioksidan Serta Penentuan Kandungan Fenolat dan Flavonoid Total dari Buah Parijoto (Medinilla speciosa Blume). [Skripsi]. Jakarta: UIN Syarif Hidayatullah.

Youngson R. 2005. Antioksidan: Manfaat Vitamin C \& E Bagi Kesehatan, Terjemahan oleh Susi Purwoko. Jakarta: Penerbit Arcan 1.

Zuhra CF., Tarigan J., Sihotang H. 2008. Aktivitas Antioksidan Senyawa Flavonoid dari Daun Katuk (Sauropus androgunus (L) Marr.) Jurnal Biologi Sumatera. 3(1): 7-10. 